\title{
Epithelial sodium channel (ENaC) (version 2019.4) in the IUPHAR/BPS Guide to Pharmacology Database
}

Israel Hanukoglu ${ }^{1}$

1. Ariel University, Israel

\begin{abstract}
The epithelial sodium channels $(\mathrm{ENaC})$ are located on the apical membrane of epithelial cells in the distal kidney tubules, lung, respiratory tract, male and female reproductive tracts, sweat and salivary glands, placenta, colon and some other organs [20, 11, 7]. In these epithelia, ENaC allows flow of Nat ions from the extracellular fluid in the lumen into the epithelial cell. $\mathrm{Na}^{+}$ions are then pumped out of the cytoplasm into the interstitial fluid by the $\mathrm{Na}^{+} / \mathrm{K}^{+}$ATPase located on the basolateral membrane 39$]$. As $\mathrm{Na}^{+}$is one of the major electrolytes in the extracellular fluid (ECF), osmolarity change initiated by the $\mathrm{Na}^{+}$flow is accompanied by a flow of water accompanying $\mathrm{Na}^{+}$ions [6]. Thus, $\mathrm{ENaC}$ has a central role in the regulation of ECF volume and blood pressure, especially via its function in the kidney $[25,30]$. The expression of $\mathrm{ENaC}$ subunits, hence its activity, is regulated by the renin-angotensin-aldosterone system, and other factors that are involved in electrolyte homeostasis [30, 1,29]. In the respiratory tract and female reproductive tract large segments of the tracts are covered by multiciliated cells. In these cells ENaC has been shown to be located along the entire length of the cilia [14]. Cilial location greatly increases $\mathrm{ENaC}$ density per cell surface and allows $\mathrm{ENaC}$ to serve as a sensitive regulator of osmolarity of the periciliary fluid throughout the whole depth of the fluid bathing the cilia [14]. In contrast to ENaC, CFTR that is defective in cystic fibrosis is not located on non-cilial cell-surface [14]. Thus, ENaC function is also essential for the clearance of respiratory airways, transport of germ cells, fertilization, implantation and cell migration [14,33]. ENaC has been recently localized in the germinal epithelium of the testis, Sertoli cells, spermatozoa, along the epididymis ducts, and smooth muscle cells $[35,36]$. Evidence has been provided that rare mutations in $\mathrm{ENaC}$ are associated with female infertility [5].
\end{abstract}

\section{Contents}

This is a citation summary for Epithelial sodium channel $(\mathrm{ENaC})$ in the Guide to Pharmacology database (GtoPdb). It exists purely as an adjunct to the database to facilitate the recognition of citations to and from the database by citation analyzers. Readers will almost certainly want to visit the relevant sections of the database which are given here under database links.

GtoPdb is an expert-driven guide to pharmacological targets and the substances that act on them. GtoPdb is a reference work which is most usefully represented as an on-line database. As in any publication this work should be appropriately cited, and the papers it cites should also be recognized. This document provides a citation for the relevant parts of the database, and also provides a reference list for the research cited by those parts.

Please note that the database version for the citations given in GtoPdb are to the most recent preceding version 
in which the family or its subfamilies and targets were substantially changed. The links below are to the current version. If you need to consult the cited version, rather than the most recent version, please contact the GtoPdb curators.

\section{Database links}

Epithelial sodium channel (ENaC)

http://www.guidetopharmacology.org/GRAC/FamilyDisplayForward?familyld=122

Introduction to Epithelial sodium channel (ENaC)

http://www.guidetopharmacology.org/GRAC/FamilyIntroductionForward?familyld=122

Channels and Subunits

Complexes

$\mathrm{ENaC} \alpha \beta \mathrm{Y}$

http://www.guidetopharmacology.org/GRAC/ObjectDisplayForward?objectld=742

Subunits

$\mathrm{ENaC} \alpha$

http://www.guidetopharmacology.org/GRAC/ObjectDisplayForward?objectld=738

$\mathrm{ENaC} \beta$

http://www.guidetopharmacology.org/GRAC/ObjectDisplayForward?objectld=739

ENaC Y

http://www.guidetopharmacology.org/GRAC/ObjectDisplayForward?objectld=741

$\mathrm{ENaC} \delta$

http://www.guidetopharmacology.org/GRAC/ObjectDisplayForward?objectld=740

\section{References}

1. Asher C, Wald H, Rossier BC and Garty H. (1996) Aldosterone-induced increase in the abundance of Na+ channel subunits. Am. J. Physiol. 271: C605-11 [PMID:8770001]

2. Baconguis I, Bohlen CJ, Goehring A, Julius D and Gouaux E. (2014) X-ray structure of acid-sensing ion channel 1-snake toxin complex reveals open state of a $\mathrm{Na}(+)$-selective channel. Cell 156: 717-29 [PMID:24507937]

3. Bize V and Horisberger JD. (2007) Sodium self-inhibition of human epithelial sodium channel: selectivity and affinity of the extracellular sodium sensing site. Am. J. Physiol. Renal Physiol. 293: F1137-46

[PMID:17670907]

4. Bogdanović R, Kuburović V, Stajić N, Mughal SS, Hilger A, Ninić S, Prijić S and Ludwig M. (2012) Liddle syndrome in a Serbian family and literature review of underlying mutations. Eur. J. Pediatr. 171: 471-8 [PMID:21956615]

5. Boggula VR, Hanukoglu I, Sagiv R, Enuka Y and Hanukoglu A. (2018) Expression of the epithelial sodium channel $(\mathrm{ENaC})$ in the endometrium - Implications for fertility in a patient with pseudohypoaldosteronism. J. Steroid Biochem. Mol. Biol. 183: 137-141 [PMID:29885352]

6. Bourque CW. (2008) Central mechanisms of osmosensation and systemic osmoregulation.Nat. Rev. Neurosci. 9: 519-31 [PMID:18509340]

7. Canessa CM, Merillat AM and Rossier BC. (1994) Membrane topology of the epithelial sodium channel in intact cells. Am. J. Physiol. 267: C1682-90 [PMID:7810611]

8. Canessa CM, Schild L, Buell G, Thorens B, Gautschi I, Horisberger JD and Rossier BC. (1994) Amiloridesensitive epithelial $\mathrm{Na}+$ channel is made of three homologous subunits. Nature 367: 463-7 [PMID:8107805]

9. Chang SS, Grunder S, Hanukoglu A, Rösler A, Mathew PM, Hanukoglu I, Schild L, Lu Y, Shimkets RA and Nelson-Williams C et al.. (1996) Mutations in subunits of the epithelial sodium channel cause salt wasting with hyperkalaemic acidosis, pseudohypoaldosteronism type 1. Nat. Genet. 12: 248-53 [PMID:8589714]

10. Collier DM and Snyder PM. (2009) Extracellular chloride regulates the epithelial sodium channel.J. Biol. Chem. 284: 29320-5 [PMID:19713212] 
11. Duc C, Farman N, Canessa CM, Bonvalet JP and Rossier BC. (1994) Cell-specific expression of epithelial sodium channel alpha, beta, and gamma subunits in aldosterone-responsive epithelia from the rat: localization by in situ hybridization and immunocytochemistry. J. Cell Biol. 127: 1907-21 [PMID:7806569]

12. Edelheit O, Ben-Shahar R, Dascal N, Hanukoglu A and Hanukoglu I. (2014) Conserved charged residues at the surface and interface of epithelial sodium channel subunits--roles in cell surface expression and the sodium self-inhibition response. FEBS J. 281: 2097-111 [PMID:24571549]

13. Edelheit O, Hanukoglu I, Shriki Y, Tfilin M, Dascal N, Gillis D and Hanukoglu A. (2010) Truncated beta epithelial sodium channel $(\mathrm{ENaC})$ subunits responsible for multi-system pseudohypoaldosteronism support partial activity of ENaC. J. Steroid Biochem. Mol. Biol. 119: 84-8 [PMID:20064610]

14. Enuka Y, Hanukoglu I, Edelheit O, Vaknine $H$ and Hanukoglu A. (2012) Epithelial sodium channels (ENaC) are uniformly distributed on motile cilia in the oviduct and the respiratory airways. Histochem. Cell Biol. 137: 339-53 [PMID:22207244]

15. Giraldez T, Rojas P, Jou J, Flores $C$ and Alvarez de la Rosa D. (2012) The epithelial sodium channel $\delta$ subunit: new notes for an old song. Am. J. Physiol. Renal Physiol. 303: F328-38 [PMID:22573384]

16. Gonzales EB, Kawate T and Gouaux E. (2009) Pore architecture and ion sites in acid-sensing ion channels and P2X receptors. Nature 460: 599-604 [PMID:19641589]

17. Hanukoglu A. (1991) Type I pseudohypoaldosteronism includes two clinically and genetically distinct entities with either renal or multiple target organ defects. J. Clin. Endocrinol. Metab. 73: 936-44 [PMID:1939532]

18. Hanukoglu A, Edelheit O, Shriki Y, Gizewska M, Dascal N and Hanukoglu I. (2008) Renin-aldosterone response, urinary $\mathrm{Na} / \mathrm{K}$ ratio and growth in pseudohypoaldosteronism patients with mutations in epithelial sodium channel (ENaC) subunit genes. J. Steroid Biochem. Mol. Biol. 111: 268-74 [PMID:18634878]

19. Hanukoglu I. (2017) ASIC and ENaC type sodium channels: conformational states and the structures of the ion selectivity filters. FEBS J. 284: 525-545 [PMID:27580245]

20. Hanukoglu I and Hanukoglu A. (2016) Epithelial sodium channel (ENaC) family: Phylogeny, structurefunction, tissue distribution, and associated inherited diseases. Gene 579: 95-132 [PMID:26772908]

21. Horisberger JD and Chraïbi A. (2004) Epithelial sodium channel: a ligand-gated channel?Nephron Physiol 96: p37-41 [PMID:14988660]

22. Jasti J, Furukawa H, Gonzales EB and Gouaux E. (2007) Structure of acid-sensing ion channel 1 at 1.9 A resolution and low $\mathrm{pH}$. Nature 449: 316-23 [PMID:17882215]

23. Kashlan $\mathrm{OB}$ and Kleyman TR. (2012) Epithelial $\mathrm{Na}(+)$ channel regulation by cytoplasmic and extracellular factors. Exp. Cell Res. 318: 1011-9 [PMID:22405998]

24. Kellenberger S, Gautschi I and Schild L. (2003) Mutations in the epithelial Na+ channel ENaC outer pore disrupt amiloride block by increasing its dissociation rate. Mol. Pharmacol. 64: 848-56 [PMID:14500741]

25. Kellenberger S and Schild L. (2015) International Union of Basic and Clinical Pharmacology. XCI. structure, function, and pharmacology of acid-sensing ion channels and the epithelial $\mathrm{Na}+$ channel. Pharmacol. Rev. 67: 1-35 [PMID:25287517]

26. Kleyman TR, Carattino MD and Hughey RP. (2009) ENaC at the cutting edge: regulation of epithelial sodium channels by proteases. J. Biol. Chem. 284: 20447-51 [PMID:19401469]

27. Lingueglia E, Voilley N, Waldmann R, Lazdunski M and Barbry P. (1993) Expression cloning of an epithelial amiloride-sensitive $\mathrm{Na}+$ channel. A new channel type with homologies to Caenorhabditis elegans degenerins. FEBS Lett. 318: 95-9 [PMID:8382172]

28. Lu M, Echeverri F, Kalabat D, Laita B, Dahan DS, Smith RD, Xu H, Staszewski L, Yamamoto J and Ling J et al.. (2008) Small molecule activator of the human epithelial sodium channel.J. Biol. Chem. 283: 1198194 [PMID:18326490]

29. Palmer LG, Patel A and Frindt G. (2012) Regulation and dysregulation of epithelial $\mathrm{Na}+$ channels.Clin. Exp. Nephrol. 16: 35-43 [PMID:22038262]

30. Rossier BC, Baker ME and Studer RA. (2015) Epithelial sodium transport and its control by aldosterone: the story of our internal environment revisited. Physiol. Rev. 95: 297-340 [PMID:25540145]

31. Rossier BC and Stutts MJ. (2009) Activation of the epithelial sodium channel (ENaC) by serine proteases. 
Annu. Rev. Physiol. 71: 361-79 [PMID:18928407]

32. Rotin D and Staub O. (2011) Role of the ubiquitin system in regulating ion transport.Pflugers Arch. 461: 121 [PMID:20972579]

33. Ruat M, Traiffort E, Arrang JM, Tardivel-Lacombe J, Diaz J, Leurs R and Schwartz JC. (1993) A novel rat serotonin (5-HT6) receptor: molecular cloning, localization and stimulation of cAMP accumulation.

Biochem. Biophys. Res. Commun. 193: 268-76 [PMID:8389146]

34. Saxena A, Hanukoglu I, Strautnieks SS, Thompson RJ, Gardiner RM and Hanukoglu A. (1998) Gene structure of the human amiloride-sensitive epithelial sodium channel beta subunit. Biochem. Biophys. Res. Commun. 252: 208-13 [PMID:9813171]

35. Sharma S, Hanukoglu A and Hanukoglu I. (2018) Localization of epithelial sodium channel (ENaC) and CFTR in the germinal epithelium of the testis, Sertoli cells, and spermatozoa. J. Mol. Histol. 49: 195-208 [PMID:29453757]

36. Sharma $S$ and Hanukoglu I. (2019) Mapping the sites of localization of epithelial sodium channel (ENaC) and CFTR in segments of the mammalian epididymis. J. Mol. Histol. 50: 141-154 [PMID:30659401]

37. Sheng S, Maarouf AB, Bruns JB, Hughey RP and Kleyman TR. (2007) Functional role of extracellular loop cysteine residues of the epithelial $\mathrm{Na}+$ channel in $\mathrm{Na}+$ self-inhibition. J. Biol. Chem. 282: 20180-90 [PMID:17522058]

38. Shimkets RA, Warnock DG, Bositis CM, Nelson-Williams C, Hansson JH, Schambelan M, Gill Jr JR, Ulick S, Milora RV and Findling JW et al.. (1994) Liddle's syndrome: heritable human hypertension caused by mutations in the beta subunit of the epithelial sodium channel. Cell 79: 407-14 [PMID:7954808]

39. Vinciguerra M, Mordasini D, Vandewalle A and Feraille E. (2005) Hormonal and nonhormonal mechanisms of regulation of the NA,K-pump in collecting duct principal cells. Semin. Nephrol. 25: 312-21 [PMID:16139686]

40. Voilley N, Bassilana F, Mignon C, Merscher S, Mattéi MG, Carle GF, Lazdunski M and Barbry P. (1995) Cloning, chromosomal localization, and physical linkage of the beta and gamma subunits (SCNN1B and SCNN1G) of the human epithelial amiloride-sensitive sodium channel. Genomics 28: 560-5 [PMID:7490094]

41. Waldmann R, Champigny G, Bassilana F, Voilley N and Lazdunski M. (1995) Molecular cloning and functional expression of a novel amiloride-sensitive Na+ channel. J. Biol. Chem. 270: 27411-4 [PMID:7499195]

42. Zennaro MC, Hubert EL and Fernandes-Rosa FL. (2012) Aldosterone resistance: structural and functional considerations and new perspectives. Mol. Cell. Endocrinol. 350: 206-15 [PMID:21664233] 